\title{
Pendidikan Dan Independensi Perempuan Masa Kini
}

\author{
Hermanto \\ Dosen STAI Al-Gazali Soppeng
}

\begin{abstract}
Education is a right for every person in the world. Therefore, there is no excuse to discriminate the education for women in Indonesia. This article is targeted to discuss the importance of education and independence of women, especially the independence of the family economy area. Woman who has a wider knowledge and more competent economic skill will be more independent, strong, and will be more successful to run her role and her function in the family, society, and national development.
\end{abstract}

Keywords: Education, Independence of women

\section{Latar Belakang}

Dalam era globalisasi di awal abad ke-21 ini, isu mengenai tingkat pendidikan, independensi, peran, fungsi dan masalahnya dalam keluarga maupun masyarakat merupakan isu yang tidak saja menarik tetapi juga sangat relevan untuk dibicarakan.

Perempuan memiliki peran dan fungsi yang sangat strategis dalam keluarga dan masyarakat. Sayangnya, banyak yang tidak bisa memainkan peran dan fungsinya dengan baik karena faktor kemiskinan dan salah satu penyebab utama terjadinya kemiskinan ini adalah rendahnya tingkat pendidikan perempuan. Oleh karena itu maka ada dua aspek yang menjadi kunci utama untuk lebih memberdayakan perempuan, yaitu pendidikan dan ekonomi. Kebijakan di bidang pendidikan dan ekonomi bagi perempuan ini sangat perlu diperhatikan sebab jika ekonomi perempuan itu kuat, maka peran mereka dalam keluarga maupun masyarakat juga akan kuat. Begitu pula dengan pendidikannya, apabila perempuan memiliki pengetahuan yang luas dan tingkat pendidikan yang tinggi, maka peran mereka secara mikro dalam keluarga akan tinggi, bahkan peran sosial perempuan dalam masyarakat juga tinggi. Pada tingkat keluarga sebagai unit dasar dalam membentuk masyarakat 
persepsi yang tidak sama antar anggota keluarga dapat menimbulkan kesenjangan antara fakta dan harapan dalam mewujudkan keluarga yang aman tentram bahagia sejahtera, akibatnya dapat menimbulkan banyak konflik dalam keluarga itu sendiri sehingga dapat pula mengancam ketahanan keluarga. Yang perlu diperhatkan adalah konflik ekonomi dan nilai-nilai dalam keluarga karena dapat merapuhkan institusi keluarga serta menimbulkan gejolak sosial yang tidak diinginkan. Untuk mencegah atau mengurangi konflik-konflik tersebut maka peranan pendidikan bagi perempuan sangat membantu untuk mengatasi masalah dan konflik-konflik tersebut.

Sekalipun pendidikan merupakan hak seluruh rakyat Indonesia, namun kenyataannya masih terdapat kesenjangan pendidikan. Kesenjangan perempuan dan laki-laki masih nampak ada. Data BPS pada tahun 2015 menunjukkan bahwa pada kelompok usia 20 - 44 tahun, laki-laki buta huruf sebesar 4 per 100 orang, sedangkan perempuan sebesar 9 per 100 orang. Menurut World Education Report (1995), banyak anak perempuan yang meninggalkan sekolah di tingkat dasar pertama pada usia 11 tahun yang putus sekolah, ini disebabkan karena faktor kesulitan ekonomi. $^{10}$

Hasil penelitian Valentina Sagala juga mengemukakan bahwa pada tahun 2006 Angka Partisipasi Sekolah (APS) laki-laki lebih tinggi dari perempuan, untuk kelompok usia 7-12 tahun angka partisipasi sekolah laki-laki (96,48 \%) lebih tinggi dari perempuan $(96,21 \%)$, dan pada klompok usia 16-18 tahun angka partisipasi sekolah laki-laki $(52,48 \%)$ sedangkan perempuan $(50,46 \%)$. Hasil analisis data 1992-2002 menunjukkan adanya gejala makin tinggi jenjang pendidikan semakin rendah angka partisipasi siswa perempuan. ${ }^{11}$ Melihat keadaan ini maka perlu adanya upaya untuk menumbuhkan kometmen dan dukungan yang kuat dari pemerintah daerah dan Dewan Perwakilan Rakyat dalam mewujudkan pendidikan bagi anak lakilaki dan

\footnotetext{
${ }^{10}$ Anggit Pulungsih. Pemberdayaan Pendidikan Perempuan. $\quad$ www.dikdasmen.org/? hal=233\&id=1122\&id_kat=dikdasmen\&s_volume\%5B0\%5D=\&hal_ini=31 diakses 27 Desember 2018.

${ }^{11}$ Valentina Sagala. Pendidikan bagi Anak Perempuan. www.pikiran-rakyat.com/cetak/ 2007/072007/23/0902.htm. diakses 27 Desember 2018
} 
perempuan. Upaya lain adalah meningkatkan keikutsertaan perempuan Indonesia dalam berbagai aktivitas ekonomi sehingga menjadi perempuan yang mengerti hak-haknya dan berani memperjuangkan hak-haknya tersebut, mandiri, tidak selalu bergantung pada suami atau orang lain, dan memiliki penghasilan sendiri.

Tulisan ini bertujuan untuk membahas pentingnya pendidikan bagi perempuan Indonesia sebagai bekal hidup yang lebih bahagia sejahtera, berkualitas tinggi, dan mandiri serta lebih memberdayakan perempuan baik dalam institusi keluarga maupun dalam masyarakat dan pembangunan nasional.

\section{Pendidikan Bagi Perempuan}

Pendidikan adalah hak setiap orang, baik laki-laki maupun perempuan. Dengan demikian, semestinya tidak ada alasan untuk mendiskriminasikan ataupun menelantarkan pendidikan kaum perempuan. Ini berarti perempuan bisa belajar bidang apa saja. Memang secara umum sebagaian besar orang tua di Indonesia saat ini sudah mulai menyadari akan pentingnya sekolah bagi putra-putrinya namun ada sebagian yang masih memiliki pandangan yang timpang terhadap pendidikan anak

perempuannya. Jika di telusuri ketimpangan pendidikan perempuan di Indonesia ini dikarenakan oleh beberapa hal antara lain: masyarakat masih berpandangan male oriented atau lebih mengutamakan pendidikan anak laki-laki dari pada anak perempuannya. $^{12}$ Male oriented juga berkaitan dengan budaya yang telah mengakar kuat dengan anggapan bahwa perempuan tidak sepantasnya berpendidikan tinggi karena nantinya hanya akan ke dapur. Persepsi ini tidak diluruskan dan tidak disadari bahwa sesungguhnya peran di dapur pun menuntut ilmu dan pengetahuan. Tanpa tahu nutrisi yang baik yang diperlukan tubuh untuk kesehatan, pertumbuhan dan perkembangan anak, mustahil perempuan dapat menyiapkan menu makanan dengan baik dan menarik sesuai dengan kebutuhan gizi keluarga. Budaya bahwa perempuan

\footnotetext{
${ }^{12}$ Sriwening. Peranan Pendidikan Konsumen Dalam Mencapai Kesejahteraan Keluarga dan Masyarakat, Pidato Karya Ilmiah, 1995
} 
adalah konco wingking, sehingga tidak perlu menempuh pendidikan yang lebih tinggi, dan faktor kemiskinan atau keterbatasan penghasilan orang tua kadang-kadang juga dapat memarginalkan pendidikan perempuan. Harus diakui faktor biaya pendidikan saat ini yang dirasa masih mahal merupakan kendala utama bagi anak anak kurang mampu untuk terus menempuh pendidikan. Selain faktor-faktor di atas, adanya trens bahwa perempuan yang mengenyam pendidikan tinggi kemudian tidak mengembangkan karirnya dan lebih memilih kembali ke ruang domistik atau memilih menjadi ibu rumah tangga, banyak menimbulkan persepsi bahwa memang tugas perempuan itu mengurus rumah tangga dan ini tidak dianggap sebagai pilihan yang disadari secara penuh.

Pada zaman yang modern ini boleh saja perempuan memilih menjadi pengurus rumah tangga (ibu rumah tangga) secara total tetapi hendaknya menjadi ibu rumah tangga yang berwawasan luas, handal dan berdaya. Hal ini dapat dicapai salah satunya dengan pendidikan, pelatihan, terus belajar untuk selalu meningkatkan pengetahuan dan keterampilannya. Sehubungan dengan hal tersebut diatas maka pemerintah, dalam hal ini adalah Departemen Pendidikan dan Kebudayan mengembangkan pendidikan ketrampilan pada Sekolah Lanjutan Tingkat Pertama (SLTP) sebagai satuan atau muatan program pada SLTP, untuk mengisi ketentuan pada pasal 4 dan pasal 13 Undang-Undang Sistem Pendidikan Nasional (UUSPN) No. 2 tahun 1989, dan pasal 3 beserta penjelasan PP No. 28 tahun 1990. ${ }^{13}$ Program ketrampilan pada Sekolah Lanjutan Tingkat Pertama ini diselenggarakan untuk menanggapi masalah-masalah nasional yang perlu mendapat perhatian dari dunia pendidikan. Masalah-masalah tersebut antara lain: tingginya angka putus sekolah, pengangguran, kemiskinan, rendahnya kualitas angkatan kerja, kurang mulusnya peran pendidikan sekolah dalam "link and match" antara peserta didik dan perannya dalam masyarakat. Program ketrampilan pada Sekolah Lanjtan Tingkat Pertama ini sebagai sub-sistem dari sistem pendidikan dasar, yang bertujuan untuk memberikan bekal kemampuan dasar yang merupakan perluasan serta peningkatan pengetahuan dan keterampilan

\footnotetext{
${ }^{13}$ Sukamto. AlternatifPengembangan Program Pendidikan Ketrampilan SLTP, (Jakarta: Penerbit Erlangga,1 994), h. 10
} 
yang diperoleh di sekolah dasar, yang bermanfaat bagi siswa untuk mengembangkan kehidupannya sebagai pribadi, anggota masyarakat dan warga negara sesuai dengan tingkat perkembangannya. Secara khusus, program pendidikan keterampilan pada SLTP ini menjadi bagian integral program pengembangan sumberdaya manusia di daerah setempat, yang diharapkan dapat memberikan pengetahuan dan keterampilan sebagai bekal menjadi manusia yang produktif, yang mampu meningkatkan taraf hidupnya, terutama bagi mereka yang tidak melanjutkan ke jenjang pendidikan yang lebih tinggi. Program pendidikan keterampilan ini berorientasi kepada kebutuhan lingkungan, dan disesuaikan dengan tingkat kemampuan penguasaan anak didik pada usia SLTP. Beberapa program pendidikan ketrampilan yang dapat dikembangkan antara lain adalah keterampilan: Bangunan, Pengerjaan Logam, Listrik dan Elektronika, Otomotif, Pertanian dan Pengelolaan Hasil Pertanian, Kerajinan, Kerumahtanggaan dan Kepariwisatan, serta Ketrampilan Niaga. Jenis- jenis ketrampilan ini masih terbuka untuk terus dikembangkan dan disesuaikan dengan kebutuhan daerah setempat. ${ }^{14}$

Penyelenggaraan program pendidikan keterampilan pada SLTP merupakan bagian integral pembangunan daerah setempat dalam fungsi pengembangan sumberdaya manusia. Oleh karena itu, peran Pemerintah Daerah sangat penting dalam mengkoordinasikan program ini ke dalam program pembangunan daerahnya. Penyelenggaraan program pendidikan keterampilan pada SLTP bersifat luwes sesuai kebutuhan daerah setempat (muatan lokal) dan diutamakan di daerah-daerah yang tergolong kantong-kantong kemiskinan atau daerah yang tinggi angka putus sekolahnya atau tinggi angka tidak melanjutkan ke jenjang sekolah yang lebih tinggi. Program keterampilan SLTP dapat menjadi program yang efektif selama diselenggarakan sesuai dengan sifatnya sebagai remidial; peluang untuk

\footnotetext{
14 Slamet P.H. Pendidikan dan Pelatihan Kejuruan dalam Era Kompetisi Global. Makalah pada
} seminar FPTK, 1994. 
meningkatkan kualitas keterampilan dasar melalui pendikan dasar hanya dapat dicapai dengan menggali secara mendalam arti dan hakikat basic skills tersebut dan berupaya mengembangkannya dengan pendekatan dan medium yang tepat. Banyak faktor yang menyebabkab para perempuan Indonesia tidak memiliki keterampilan, antara lain adalah: sedikitnya kesempatan memperoleh keterampilan yang sesuai dengan kebutuhan setempat, faktor kemiskinan, tidak adanya semangat dan kemauan untuk memperoleh kesempatan dan fasilitas berlatih keterampilan dengan baik, meskipun otaknya mungkin cemerlang. Tingkat pendidikan dan pengetahuan serta ketrampilan yang rendah bagi perempuan menyebabkan mereka menjadi sumberdaya manusia yang kurang mampu bersaing di dunia kerja. Agar memiliki kemampuan bersaing, salah satunya adalah menjadi manusia yang berkualitas tinggi. Sumber daya manusia yang berkualitas tinggi ini dapat dihasilkan salah satunya melalui jalur pendidikan dan pelatihan dengan sistem pemagangan.

Para ahli ekonomi (Tucker, 1991 dan Carnevale, 1994) berpendapat bahwa keunggulankeunggulan yang diperlukan dalam era kompetisi global adalah sebagai berikut:

1. Sumberdaya Buatan Manusia (Teknologi)
a. Teknologi Manufaktur
b. Teknologi Transportasi
c. Teknologi Komunikasi
d. Teknologi Konstruksi
e. Teknologi Energi dll

2. Sumberdaya Manusia yang memiliki:

a. Keterampilan pokok yang terdiri dari:

- Keterampilan dasar: membaca, menulis, berhitung dan matematika, berbicara dan mendengar. 


\section{An-Nisa', Volume XI Nomor 2 Desember 2018}

- Keterampilan berpikir: kemampuan belajar, beralasan, berfikir kritis, berfikir kreatif, mampu menngambil keputusan, dan memecahkan masalah.

- Kualitas pribadi: memiliki rasa tanggung jawab yang tinggi, harga diri, manajemen diri, sosiabilitas dan integritas (employability skills).

b. Keterampilan kerja:

- Sumberdaya: mereka tahu bagaimana mengalokasikan waktu, uang, bahan, ruang, dan staf.

- Keterampilan interpersonal: mereka dapat bekerja secara kelompok, mau mengajari temannya, melayani pelanggan, memimpin, bernegosiasi, dan bekerja dengan baik meskipun dengan orang-orang yang memiliki latar belakang budaya yang berbeda.

- Informasi: Mereka mampu mendapatkan dan mengevaluasi data, mengorganisasi dan memelihara arsip, menginterpretasi dan mengkomunikasikan serta menggunakan komputer untuk memproses informasi.

- Sistem: mereka memahami sistem sosial, organisasi dan teknologi; mereka mampu memonitor dan meluruskan kinerja; dan mereka mampu merancang atau memperbaiki sistem.

- Teknologi: mereka mampu memilih alat dan perlengkapan, menerapkan teknologi terhadap tugas khusus, memelihara dan mencari serta memecahkan masalah perlenkapannya.

Untuk memastikan terpenuhinya hak perempuan dan laki-laki akan pendidikan maka perlu segera meningkatkan akses dan perluasan kesempatan belajar bagi anakanak perempuan dan laki-laki usia sekolah terutama di daerah miskin, terpencil, dan terisolasi. Membuka sekolah kejuruan yang relevan dengan kebutuhan pemberdayaan perempuan dan masyarakat setempat,responsif dan antisipatif serta dapat membantu pencapaian tujuan sosial yang dapat menjamin akses dan ekuitas peserta didik, berikutnya memperbaiki mutu pendidikan dan meningkatkan kesempatan bagi 
perempuan untuk menjamin bahwa perempuan memperoleh pengetahuan dan keterampilan, sehingga diharapkan dapat terwujud kesetaraan dan keadilan gender.

Pendidikan adalah salah satu jalan menjadikan perempuan sebagai agen perubahan, bukan sekedar penerima pasif program-program pemberdayaan. Pendidikan juga dapat menjadi salah satu faktor yang memungkinkan perempuan memiliki independensi (kemandirian) ekonomi dengan bekerja baik di luar maupun di dalam rumah tinggalnya.

Independensi ekonomi ini membuat perempuan memiliki suara baik di dalam keluarga maupun di masyarakat, contohnya antara lain dalam pengaturan keuangan keluarga untuk gizi makanan, biaya kesehatan, pendidikan anak dan lain-lain. Perempuan yang memiliki sumber penghasilan di tanganya, cenderung membelanjakan penghasilannya itu untuk kesejahteraan dan peningkatan kualitas hidup anak-anaknya sebagai generasi muda penerus bangsa. Dengan demikian pendidikan sangat penting bagi perempuan karena kontribusinya terhadap upaya menyiapkan generasi penerus bangsa yang berkualitas unggul sangat besar.

\section{Peranan Perempuan dalam Keluarga dan Masyarakat}

Secara alamiah, perempuan berbeda dengan laki-laki baik secara fisik maupun secara psikologi. Secara fisik, perbedaan itu sangat jelas. Perempuan dapat melahirkan, dan secara psikologis, laki-laki biasanya lebih aktif, agresif dan lebih rasional. Oleh karena itu wajar kalau banyak masyarakat yang menganggap perempuan harus hidup di lingkungan keluarganya. Tugas ini adalah tugas yang diberikan alam kepada kaum perempuan karena harus melahirkan dan membesarkan anak-anaknya di lingkungan keluarga supaya rumah tangganya lebih tentram, damai, bahagia, dan sejahtera. Demikian juga pembagian kerja secara seksual sebenarnya sudah dilakukan sejak jaman dahulu. Laki-laki mempunyai tugas mencari nafkah dan bekerja untuk keluarganya, sedangkan perempuan lebih bersifat sebagai pengelola dan pengatur di dalam rumah. Sejalan dengan perkembangan jaman, tugas perempuan masih tetap tidak dapat dilepaskan dari kehidupan keluarga sebagai pengelola dan pengatur kehidupan keluarga, yang mana peran-peran seperti itu masih merupakan kewajiban bagi kaum perempuan, walaupun tidak dapat dipungkiri tugas-tugas lain juga menuntut pula partisipasi dari kaum perempuan. 


\section{An-Nisa', Volume XI Nomor 2 Desember 2018}

Kedudukan perempuan dan laki-laki adalah sama, tetapi kenyataannya masih banyak budaya yang beranggapan perempuan berbeda dengan laki-laki. Sehingga diberi peran yang berbeda pula untuk bisa saling melengkapi di antara keduanya, supaya mereka dapat memecahkan permasalahan secara baik dan bijaksana. Oleh karena itu peran perempuan sebagai pengelola dalam kehidupan keluarga merupakan hal yang dianggap wajar meskipun pekerjaan ini tidak dapat dianggap mudah dan perlu diperhatikan sungguh-sungguh.

Salah satu segi yang penting di dalam pengelolaan kehidupan keluarga adalah pengelolaan keuangan. Di mana masalah ini merupakan suatu hal yang sangat berperan di dalam membina keluarga yang bahagia dan sejahtera. Di dalam mengelola keuangan keluarga, banyak faktor yang mempengaruhi anatara lain: keadaan sosial ekonomi, besar keluarga, lingkungan tempat tinggal, tingkat pendidikan, dan gaya hidup. Sehubungan dengan itu maka peranan perempuan dalam hal ini adalah ibu sebagai salah seorang pembina, pengelola, dan penggerak kehidupan keluarga. Dengan demikian tentu akan mempengaruhi pengambilan keputusan dan pemenuhan kebutuhan setiap keluarga. Perempuan sebagai pengelola keluarga yang baik, prinsipnya harus dapat mengendalikan keuangan rumah tangga. Oleh karena itu, peranan perempuan sebagai pengelola keuangan keluarga sangat besar. Sewajarnyalah kalau perempuan harus memiliki pengetahuan bagaimana membuat perencanaan, melakasanakan dan mengevaluasi pengelolaan keuangan kekuarga dengan baik, agar keluarga lebih sejahtera. Yang dimaksud dengan keluarga sejahtera adalah tercapainya suatu keadaan dimana keamanan, kedamaian, dan ketentraman, serta kebahagiaan tercipta secara kondusif dalam keluarga karena terpenuhinya kebutuhan lahir maupun batin pada setiap anggota nya.

Meskipun bahagia itu relatif sifatnya tetapi pada umumnya memiliki ciri-ciri yang dapat digunakan sebagai indikator tercapainya kebahagiaan dalam keluarga, ciri-ciri tersebut adalah:

1. Saling mengerti antara suami dan istri, hormat menghormati, dan saling menghargai, sehingga terbinalah suatu kehidupan yang rukun dan damai. 
2. Setia dan saling menyayangi dengan penuh cinta, sehingga dapat tercapai ketentraman dan kedamaian lahir maupun batin yang dapat menjadi dasar utama kekalnya hubungan.

3. Mampu menghadapi persoalan-persoalan dan kesulitan-kesulitan, sehingga dapat memecahkan masalah-masalah yang dihadapi.

4. Saling membantu dalam memikul tugas kerumahtanggaan, sehingga beban disandang menjadi lebih ringan.

5. Tidak berbuat yang dapat menimbulkan kecurigaan, kegelisahan, dan keretakan.

6. Dapat memahami kelemahan-kelemahan yang ada pada setiap manusia dan saling memaafkan.

7. Selalu diadakan musyawarah bila ada sesuatu kesulitan dan jangan segansegan meminta maaf jika merasa bersalah.

8. Saling berlapang dada dan terbuka, sehingga tidak ada hal yang menyulitkan dan menyiksa fikiran.

9. Hormat menghormati keluarga masing-masing, sehingga terus bisa membina keakraban dan menjalin kekerabatan dengan rukun dan damai.

10. Dapat mengusahakan sumber penghasilan yang layak untuk memenuhi kebutuhan keluarga.

11. Mengerti dan melaksanakan hak dan kewajiban masing-masing. ${ }^{15}$

Dengan demikian peran perempuan dalam keluarga memang sangat strategis, selain menjadi pendidik yang pertama dan utama dalam keluarga perempuan juga sebagai pembina, pengelola dan pengatur kehidupan keluarga dimana dalam kehidupan keluargan perempuan berkesempatan dan berhubungan mesra dengan suami, anak, serta masyarakat luas. Perempuan merupakan teman hidup, kasih yang hangat bagi suami, ibu yang penuh kasih sayang dan perhatian bagi putra-putrinya. Perempuan

15 Sriwening. Peranan Pendidikan Konsumen Dalam Mencapai Kesejahteraan Keluarga dan Masyarakat. Pidato Karya Ilmiah, 1995. 


\section{An-Nisa', Volume XI Nomor 2 Desember 2018}

juga berperan untuk memancarkan kehangatan dalam kehidupan keluarganya.atan memainkan peran sebagai mahluk sosial. Syukurlah di zaman kemerdekaan ini emansipasi kaum perempuan sudah bukan lagi menjadi masalah.

Dengan kegotongroyongan yang didasari falsafah Pancasila kaum perempuan dan kaum laki-laki mempunyai posisi yang sama tinggi. Dalam kehidupan keluarga serta kehidupan masyarakat modern, kaum perempuan dan laki-laki, suami dan isteri memiliki kedudukan dan peran yang seimbang serta selaras. Yang masih menjadi masalah saat ini adalah bagaimana memberikan kesempatan kepada perempuan agar lebih berperanserta dalam pembangunan nasiona. Perempuan masa kini masih tetap memegang teguh peranan yang telah menjadi bagian dari dirinya itu, ditambah dengan tanggung jawabnya membina generasi muda, bertanggung jawab terhadap negara dan bangsa serta ikut aktif membangun bangsa. Supaya perempuan Indonesia dapat lebih berperan dalam keluarga maupun msyarakat dan pembangunan nasional dengan baik, maka kemandirian perempuanlah yang akan dapat menjawab tantangan pembangun tersebut.

\section{Independensi Perempuan}

Independensi perempuan sering diartikan dengan kemandirian kaum perempuan, sehingga tidak bergantung pada orang lain dan suami dalam urusan ekonomi dan peningkatan taraf hidup keluarga. Perempuan yang mandiri akan dapat lebih berdaya baik dalam keluarga maupun masyarakat.

Jumlah perempuan yang telah menempuh pendidikan di perguruan tinggi pada saat ini sudah tentu lebih banyak dari pada masa tahun 70-80an. Seiring dengan semakin terbukanya kesempatan itu tentu saja banyak angan-angan dan harapan yang ingin diraih. Sebagaian ada yang ingin bekerja setelah menamatkan pendidikannya, sebagian ada yang ingin menjadi ibu rumah tangga saja tetapi memiliki pengetahuan dan wawasan yang luas, serta ketrampilan yang beraneka ragam, tetapi ada yang tidak memaksakan diri dan hanya menerima apa adanya tergantung keadaan, ada yang 
ingin bekerja di kantor, di bidang manufaktur, di bidang entertainment, atau enterpreneurship, bidang pertanian, peternakan dan perikanan, serta dibidang kepariwisataan.

Peran perempuan dalam pembangunan masih sering diabaikan, terutama di negara-negara berkembang. Posisinya dalam pembangunan masih sering di bawah laki-laki. Akhir-akhir ini banyak program-program pemberdayaan perempuan telah dilaksankan oleh pemerintah atau Lembaga Sosial Kemasyarakatan (LSM). Dengan memberdayakan perempuan, diharapkan akan meningkatkan kemandiriannya. Kemandirian yang dimiliki oleh seorang perempuan, misalnya dalam bidang ekonomi, dapat meningkatkan pendapatan rumah tangganya, dan jika hal ini dilakukan oleh perempuan secara tidak langsung maka akan meningkatkan income per capita suatu daerah. Seberapa besar pemberdayaan perempuan dapat berpengaruh dalam bidang pembangunan ekonomi? Ini dapat dicari melaluhi hubungan keduanya dengan analisis statistik seperti yang di kemukakan di Kompas, 31 Oktober 2007 sebagai berikut: Hasil analisis statistik terhadap data tahun 2002 dapat disimpulkan bahwa ada korelasi positif antara pemberdayaan perempuan dengan pembangunan bidang ekonomi. Beberapa variabel pemberdayaan perempuan, seperti jumlah penduduk perempuan, usia harapan hidup, angka melek huruf, rata-rata lama sekolah, kontribusi dalam pendapatan, perempuan dalam parlemen, perempuan dalam angkatan kerja, dan rata-rata upah di sektor non-pertanian, berpengaruh terhadap peningkatan pertumbuhan ekonomi.

Hasil ini semakin mempertegas pentingnya peran pemberdayaan perempuan khususnya untuk mendukung kemandiriannya, dan dalam pembangunan pada umumnya. Semakin tinggi aspek-aspek pemberdayaan perempuan akan memberikan kontribusi yang besar dalam pembangunan, khususnya peningkatan laju pertumbuhan ekonomi. $^{16}$ Dari delapan variabel tersebut di atas yang memiliki nilai korelasi paling

${ }^{16}$ Putri Rosalina M. Upaya Sederhana Perkuat Keterlibatan Kaum Hawa. Harian Kompas: 31 Oktober 2007. 
besar dengan laju pertumbuhan ekonomi berturut-turut adalah: rata-rata lama sekolah. Berikutnya variabel kontribusi dalam pndapatan, rata upah di sektor non-pertanian, perempuan dalam angkatan kerja angka melek huruf, harapan hidup, jumlah populasi, dan perempuan dalam parlemen. Dari hasil tersebut dapat di tunjukkan bahwa kemandirian perempuan yang paling utama harus dimulai dari sektor pendidikan. Menurut Wrihatnolo dan Dwijowijoto (2007) dalam Kompas tanggal 30 Oktober 2007 mengemukakan bahwa ada tiga tahapan proses pemberdayaan itu. Pertama, penyadaran dengan target yang hendak disadarkan diberi pencerahan dahulu dalam bentuk pemberian penyadaran bahwa mereka memiliki hak untuk memiliki sesuatu. Prinsipnya membuat si target mengerti bahwa mereka perlu diberdayakan dan proses pemberdayaan itu dimulai dari dalam diri diri mereka. Kedua adalah diberikan daya kuasa pada yang bersangkutan agar mampu terlebih dahulu. Proses pembentukan kapasitas ini terdiri atas manusia, organisasi, dan sistem nilai. Ketiga, target diberi daya kekuasaan, otoritas, dan peluang. Ciri khas penerapan pemberdayan masyarakat ada enam yakni adanya stimulus modal, dilakukan pendampingan, ada bantuan sarana dan prasarana, pengembangan kelembagaan, dilakukan monitoring dan evaluasi, serta pelaporan. ${ }^{17}$ Agar lebih berdaya banyak perempuan yang memilih bekerja di sektor bisnis. Ada beberapa alasan mengapa seorang perempuan bekerja di dalam organisasi bisnis, seperti yang dikemukakan oleh Shanti L. Poesposoetjipto sebagai berikut: karena faktor ekonomi, karena orangtua telah memberikan kesempatan bagi si perempuan untuk menuntut ilmu, sehingga ia memiliki suatu keahlian yang memungkinkan bagi yang bersangkutan untuk mencari nafkah sendiri, karena memang secara sadar ingin meniti karir. ${ }^{18}$

17 Evi Rahmawati dan Putri Rosalia. Kemandirian Para Perempuan Tiga Kota. Harian Kompas: 30 Oktober 2007

18 Shanti L. Poesposoetjipto. Perempuan Manajer Peluang dan Tantangan. Dalam kumpulan artikel " Perempuan Indonesia”. Pustaka Sinar Harapan, 1991. 
Pengakuan seorang ibu beranak tiga (dalam usia sekolah), ia bekerja sebagai tenaga jahit di sebuah garmen karena ingin meningkatkan taraf hidup keluarganya, alasan ia gigih bekerja semula karena suami yang tidak memiliki penghasilan tetap, dan kadang-kadang jatah uang belanja dihabiskan untuk berjudi. Alasan inilah sesungguhnya yang menguatkan dirinya untuk berusaha bekerja dengan tekun, gigih, dan penuh semangat untuk terus berjuang demi perbaikan taraf hidup keluarganya. Kemandiriannya dalam ekonomi keluarganya ini ternyata dapat membuat perempuan desa ini memiliki daya tawar terhadap sang suami dalam urusan ekonomi keluarganya, buktinya ia juga ikut menentukan harga jual hasil panen sawahnya yang semula hanya ditentukan oleh suami. Perempuan berpendidikan dan memiliki kemandirian ekonomi akan lebih memiliki akses informasi yang lebih baik dari pada beberapa perempuan yang tidak sempat menambah ilmu pengetahuannya dan mengembangkan diri serta wawasannya baik melalui pelatihan program-progam pemberdayaan perempuan atau kegiatan lainnya karena disibukkan dengan berbagai pekerjaan, mulai dari pekerjaan rumah tangga yang tidak ada habis-habisnya, merawat dan mengasuh anak dari bangun tidur sampai anak tidur kembali, melayani suami,dan kesibukan yang lainnya. Kesibukan yang sangat padat dan masalah ekonomi inilah yang menjauhkan perempuan dari sumber-sumber informasi yang sesungguhnya sangat penting bagi kemandirian dirinya. ${ }^{19}$ Mulai saat ini perempuan indonesia haruslah menyadari untuk lebih memandirikan dirinya, dan lebih dapat memanfaatkan peluang tidak hanya di sektor ekonomi saja tetapi juga di bidang-bidang lainnya. Lihat saja wahyu pertama (QS.96:1) yang difahami sebagai perintah iqra', membaca, perintah belajar yang bersifat umum, tidak ada perbedaan laki-laki maupun perempuan. Surat 2:30, yang berbunyi "Sesungguhnya aku hendak menjadikan seorang khalifah di muka bumi ", dan Surat Hud: 61, ”

\footnotetext{
${ }^{19}$ Shanti L. Poesposoetjipto. Perempuan Manajer Peluang dan Tantangan. Dalam kumpulan artikel "Perempuan Indonesia" (Bandung: Pustaka Sinar Harapan, 1991), h. 20
} 


\section{An-Nisa', Volume XI Nomor 2 Desember 2018}

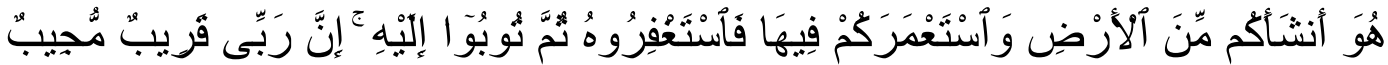

"Dan Dia yang menciptakan kamu dari bumi (tanah) dan menugaskan kamu untuk memakmurkan. karena itu mohonlah ampunan-Nya, kemudian bertobatlah kepada-Nya, Sesungguhnya Tuhanku amat dekat (rahmat-Nya) lagi memperkenankan (doa hamba-Nya).

Dengan ayat ini, manusia dituntut akan tanggungjawabnya sebagai hamba dan khalifah yang berkualitas di muka bumi”. Dan untuk menuju kesana dibutuhkan orang yang mau belajar agar tugasnya untuk mewujudkan kehidupan dunia yang adil dan makmur dapat tercapai, baik laki-laki maupun perempuan. Sama seperti halnya keimanan, keilmuan hanya dapat didapatkan melalui pengkondisian, kemauan, pencarian, dan usaha yang keras, tekun, dari semua pihak.

\section{Kesimpulan}

Pendidikan adalah hak setiap orang, baik laki-laki maupun perempuan. Dengan demikian, tidak ada alasan untuk mendiskriminasikan pendidikan perempuan indonesia. Sehubungan dengan itu maka budaya-budaya dan segala hal yang menghambat kesempatan kaum perempuan untuk mendapatkan pendidikan dan pelatihan guna meningkatkan pengetahuan dan keterampilanya harus diluruskan dan diperhatikan oleh yang berdaya seperti pemerintah, orangtua terhadap anak, orang yang kaya terhadap orang miskin karena pendidikan adalah salah satu jalan menjadikan perempuan sebagai agen perubahan dan bukan sekedar penerima program pemberdayaan secara pasif.

Pendidikan merupakan faktor utama yang memungkinkan permpuan memiliki independensi atau kemandirian yang kuat terutama kemandirian dibidang ekonomi keluarga. Dengan independensi ekonomi inilah perempuan akan dapat lebih berdaya baik dalam institusi keluarga, masyarakat maupun pembangunan. Dengan demikian perempuan diharapkan akan memiliki kontribusi yang sangat besar terhadap keamanan, kedamaian, ketenteraman, kebahagiaan, kesejahteraan dalam keluarga dan 
sosial, serta dapat menyiapkan generasi muda penerus bangsa yang unggul dan mampu bersaing di era globalisasi ini.

\section{Daftar Pustaka}

Anggit Pulungsih. Pemberdayaan Pendidikan Perempuan. www.dikdasmen.org/? hal=233\&id=1122\&id_kat=dikdasmen\&s_volume\%5B0\%5D=\&hal_ini=31

Evi Rahmawati dan Putri Rosalia. Kemandirian Para Perempuan Tiga Kota. Harian Kompas: 30 Oktober 2007.

Putri Rosalina M. Upaya Sederhana Perkuat Keterlibatan Kaum Hawa. Harian Kompas: 31 Oktober 2007.

Shanti L. Poesposoetjipto. Perempuan Manajer Peluang dan Tantangan. Dalam kumpulan artikel "Perempuan Indonesia". Pustaka Sinar Harapan, 1991.

Slamet P.H. Pendidikan dan Pelatihan Kejuruan dalam Era Kompetisi Global. Makalah pada seminar FPTK, 1994.

Sriwening. Peranan Pendidikan Konsumen Dalam Mencapai Kesejahteraan Keluarga dan Masyarakat. Pidato Karya Ilmiah, 1995.

Sukamto. AlternatifPengembangan Program Pendidikan Ketrampilan SLTP, 1994 Tucker, Robert B. Managing the Future. New York, NY: G.P Putman’s Sons, 1991.

Valentina Sagala. Pendidikan bagi Anak Perempuan. www.pikiran-rakyat.com/cetak/ 2007/072007/23/0902.htm. 23 Juli 2007. 